plan of co-operation, in order to encourage research projects of national importance.

The resoarch needs of the Chilean wood-using industry were presented by A. Pérez, the Institute's officer-incharge of forest products research. $\mathrm{H}_{\Theta}$ directed attention to tho urgent necessity for applied research and education in the basic conversion processes such as sawmilling, veneer and plywood, preservation, seasoning, and pulping, as well as for fomenting auxiliary industries such as manufacture of adhesives. The Institute's Food and Agriculture Organization adviser on research, Dr. W. G. Kauman (senior research officer, C.S.I.R.O., Division of Forest Products, Australia; on leave of absence), pointod out that of the three main types of research, that is: (1) short-term problem solving; (2) determination of basic properties; (3) academic research, the second constitutes the most urgent task for the university laboratories, but that the third must be given due importance to ensure a future supply of professional and other academic staff.

Prof. G. Mittak, of the recently formed Austral University of Valdivia, emphasized the importance his laboratory is attaching to wood anatomy, in particular identification, and to drying of difficult Nothofagus species. For the Catholic University of Santiago, H. Ayarza presented a comparison of the mechanical strength of Pinus radiata determined on small clear specimens and on commercial sizes, and work on various timber joints and connectors.
Research on timber in the Institute for Testing Materials in the University of Chile, Santiago, as outlined by $H$. Albala, is mainly concerned with mechanical strongth of Chilean timbers. Due attention is being given to statistical design of the experiments, a factor which has been largely neglected in much of the past work in Chile. Nineteen species have so far been investigated. E. Cuevas presentert work on timber physics and proservation in the Forest Enginoering School of the University of Chile. Interesting results have been obtained on the frequency distribution of density in fifteen species, and correlations of other propertios with density are being examined. E. Bluhm. of the University of Concepción, stated that his laboratory is concentrating on wood chemistry and pulp and paper, and reported a laboratory project on pulping by the nitric acid process. In the Technical University Federico Santa María of Valparaíso, forest products work so far has doalt with pulping, minor forest products and utilization of lignin. Prof. R. Ripa reported on an invostigation of production of detergents from sulphonated lignin derivatives. Prof. J. Hirschmann, of the same Univorsity, gave details of a new professional course for timber and plastics engineers, now in its third yoar.

The participants agreed on a plan for co-ordinated research on forest products proposed by Dr. W. G. Kauman, of the Instituto Forestal, and resolved to work in close collaboration to counteract the difficulties creater by the dispersion of facilities.

\title{
GAMMA-RAY STERILIZATION OF MEDICAL UTENSILS
}

$\mathrm{T}$ HE world's first privately owned cobalt-60 irradiation plant designed specifically for medical purposes began continuous operation on November 10 at Johnson's Ethical Plastics Ltd., Slough. It is to be used to sterilize disposable, or single use, plastic hypodermic syringes. The only other plants which resemble it are the United Kingdom Atomic Energy Authority's experimental unit at Wantage, Berks., and a privately owned installation in Australia used for sterilizing goat hair. The plant at Slough was designed and constructed by H. S. Marsh Ltd., Reading, in collaboration with the United Kingdom Atomic Energy Authority.

The radioactive source which emits the sterilizing $\gamma$-rays consists of 120 cobalt rods which have become radioactive by treatment in a nuclear reactor at Calder Hall. The rods have a half-life of five years. The capacity is 50,000 curies, but provision has been made to measuro the number of rods to a maximum of 720 with a possible rise to half-a-million curies. The cell in which the cobalt is loaded is a concrete block weighing some 700 tons, and occupying most of the space of the building of 2,500 sq. ft. which houses tho plant.
The main object of the disposable or single-use syringes is to reduce or avoid the incidence of cross-infection. Gamma irradiation provides the safest and surest way of assuring sterility. The syringes are made of polystyrene. the grummets of surgical rubber and the needles of stainless steel. It is claimed that it is more economical to use disposable syringes than to wash and clean glass syringes, clean and sharpen needles, and sterilize them by orthodox methods. The present production and sales of disposable syringes is more than 12 million pen: annum.

At the inauguration luncheon held on November 9 in London the guest of honour was Sir Roger Makins, chairman of the United Kingdom Atomic Energy Authority, and it was announced that to mark the occasion of the opening of the cobalt-60 plant, the Medical College of St. Bartholomew's Hospital, London, had accopted at grant of $£ 2,400$ spread over throe years made by Johnson's Ethical Plastics Ltd. The money is to be used by Prof. J. Rotblat in the Department of Physics to employ a radio-biologist as assistant in his radiation research.

\section{RESPONSE OF AN ASTATIC MAGNETOMETER TO A CYLINDRICAL ROCK SPECIMEN}

\author{
By J. L. ROY \\ Dominion Observatory, Ottawa
}

CPECIMENS of weakly magnetized rocks aro often cut $W$ in cylindrical form for measurement with an astatic magnetometer. It will be shown here that tho response of a two-magnet astatic system depends on the relative dimensions of the spocimen, that is, on the ratio of height to radius. A knowledge of the nature of this response variation is important if, as is usually the case with weakly magnetized rocks, the largest possible deflexion for a given intensity of magnetization is required. The standard practice has beon to use rock specimens in the form of thin disks. 'It is concluded that the height of eylindrical spocimens should be comparable with their diamoter.

The design thoory and description of an astatic magnetomotor can be found elsowhere ${ }^{1-3}$. In briof, the intensity and diroction of magnetization of a specimen of magnetic momont $p$ are measured by placing the centre of the specimen at a distance $z$ below the axis of the lower magnot (of the magnetometer) and at a distance $x \ll z$ from the plano of magnetization of the magnetometer. 